\title{
Choline oxidase chemiluminèscent assay, after removal of eserine from medium, of acetylcholine released in vitro from brain slices *
}

\author{
M.A.M. Prado, T. Moraes-Santos, R.N. Freitas, M.A.R. Silva and M.V. Gomez \\ Departamento de Bioquímica e Imunologia, Instituto de Ciências Biológicas UFMG, Belo Horizonte - Minas Gerais (Brazil)
}

(Received 12 July 1989)

(Revised version received 17 October 1989)

(Accepted 21 October 1989)

Key words: Acetylcholine assay; Chemiluminescent procedure; Neurotransmitter release

A chemiluminescent method has been used recently for the determination of acetylcholine with limitations such as the presence of a cholinesterase inhibitor in the incubation medium, which is indispensable for the study of acetylcholine release by various agents. A modified procedure is presented in which the cholinesterase inhibitor eserine (physostigmine) is extracted from the medium. The results showed complete recovery when labelled acetylcholine was used. This modified procedure was used to determine the release of acetylcholine evoked by tityustoxin and ouabain. The results were comparable to those obtained by bioassay using a strip of guinea pig ileum.

\section{Introduction}

Acetylcholine $(\mathrm{ACh})$ was the first neurotransmitter to be documented. ACh can be measured by several methods, such as pyrolysis, gas chromatography-mass fragmentography (Jenden et al., 1973), biological methods using guinea pig ileum or leech muscle assay (MacIntosh and Perry, 1950), radiometric enzymatic determination (Goldberg and McCannan, 1973), and HPLC with electrochemical detection (Potter et al., 1983).

Mainly due to its specificity and sensitivity the chemiluminescent procedure for ACh assay (Israel and Lesbats, 1981a) has been used intensively for the determination of this neurotransmitter during

\footnotetext{
* A preliminary communication was presented at the Meeting of the Brazilian Society for Biochemistry, Caxambu, MG, Brazil, May 1989.

Correspondence: Dr. Marcus Vinicius Gomez, Departamento de Bioquimica e Imunologia, Instituto de Ciências BiológicasUFMG, Caixa Postal, 2486 Belo Horizonte - Minas Gerais. Brazil.
}

continuous release. The method is based on the following 3 coupled enzyme reactions, whereas the choline assay involves only reactions (2) and (3):

$$
\begin{aligned}
& \text { ACh } \stackrel{\text { ACh esterase }}{\longrightarrow} \text { acetate }+ \text { choline } \\
& \text { choline } \stackrel{\text { choline oxidase }}{,} \text { betaine }+2 \mathrm{H}_{2} \mathrm{O}_{2} \\
& \mathrm{H}_{2} \mathrm{O}_{2}+\text { luminol } \stackrel{\text { microperoxidase }}{\longrightarrow} \text { light }+ \text { amino- } \\
& \text { phthalic acid }
\end{aligned}
$$

If the concentrations of all the reactants except $\mathrm{ACh}$ are kept constant then the light emitted in reaction (3) is directly proportional to the concentration of $\mathrm{ACh}$. This procedure permits the continuous monitoring of ACh release (Israel and Lesbats,1981b) and analysis of ACh from mammalian tissue extracts treated with oxidants (Israel and Lesbats, 1982). An adaptation of the method using periodate precipitation made it possible to assay endogenous $\mathrm{ACh}$ released from rat hemidiaphragm (Haggblad et al., 1983), but with a low recovery rate of $\mathrm{ACh}$. 
A modification of the method that permits the assay of ACh in incubation fluids containing the cholinesterase inhibitor eserine (physostigmine) has been developed. The assay is based on the solubility of eserine free base in benzene. Eserine free base, being an apolar compound, is thus easily extracted by several washes with benzene, while $\mathrm{ACh}$, which is a polar substance, remains in the washed extract.

The present paper describes this modification, which allows the determination of $\mathrm{ACh}$ in the presence of the cholinesterase inhibitor, eserine free base. Also, a typical application of the method for measurement of the $\mathrm{ACh}$ released from rat brain cortical slices stimulated by tityustoxin and ouabain is shown.

\section{Material and methods}

Acetylcholine chloride, eserine free base, eserine hemisulphate, ouabain, luminol (5-amino-2,3dihydro-1,4-phthalazinedione), choline oxidase, acetylcholinesterase (Electrophorus electricus) and microperoxidase were obtained from Sigma Chemical Co. (St. Louis, MO, U.S.A.). $\left[{ }^{14} \mathrm{C}\right] \mathrm{ACh}$ ( $\left[{ }^{14} \mathrm{C}\right]$ methyl chloride; $54 \mathrm{mCi} / \mathrm{mol}$ ) was from Amersham/Searle. All other chemicals were of analytical grade. Tityustoxin was purified according to a method previously described (Gomez et al., 1973).

Slices from brain cortex of Wistar rats ( 2 months old, 200-250 g) were cut on a McIlwain tissue slicer, and incubated for $30 \mathrm{~min}$ in $3.0 \mathrm{ml}$ incubation medium containing (in mmol/l): $\mathrm{NaCl} 136$; $\mathrm{KCl} 2.7 ; \mathrm{CaCl}_{2}$ 1.35; $\mathrm{NaH}_{2} \mathrm{PO}_{4} 0.36 ; \mathrm{NaHCO}_{3}$ 12; glucose 5.5; and eserine free base (physostigmine) 0.01 , brought to $\mathrm{pH} 7.4$ with $1 \mathrm{~mol} / \mathrm{A} \mathrm{HCl}$. The presence of eserine in the medium protects acetylcholine against hydrolytic action of cholinesterase during the incubation. The slices were separated from the supernatant containing released ACh by centrifugation at $2500 \times g$ for $10 \mathrm{~min}$. In order to eliminate protein interference, the supernatant was treated with $5 \%$ trichloroacetic acid and centrifuged at $10,000 \times \mathrm{g}$ for $10 \mathrm{~min}$. Trichloroacetic acid was removed by washing 4 times with diethyl ether. A $1.0-\mathrm{ml}$ aliquot of washed extract, practically free of acid ( $\mathrm{pH} 5.0-5.5)$, was then washed 6 times with $2 \mathrm{ml}$ benzene. Traces of this solvent were removed by evaporation using an $\mathrm{N}$-Evap model III apparatus (Organomation, Shrewsbury, MA). $100 \mu \mathrm{l}$ of a $0.5 \%$ sodium metaperiodate solution was added to each sample to oxidize interfering substances present in the extracted solution (Israel and Lesbats, 1982). For the non-extracted sample, trichloroacetic acid was removed by ether washing, and $\mathrm{ACh}$ analyzed by bioassay.

\section{Chemiluminescent assay for $\mathrm{ACh}$}

The assay was performed in a dark chamber with $960 \mu \mathrm{l}$ of a mixture containing $1.5 \mathrm{U}$ choline oxidase, $20 \mu \mathrm{g}$ microperoxidase, $10 \mu \mathrm{mol} / 1$ luminol and $67 \mathrm{mmol} / 1$ glycine buffer, $\mathrm{pH} 8.6$. Ten or 20 $\mu 1$ of each sample of the benzene-washed solution were added to the above medium. The first light reaction, due mainly to choline oxidation, was observed and recorded. When a steady-state line was obtained, $1.6 \mathrm{U}$ acetylcholinesterase in a volume of $20 \mu \mathrm{l}$ was added. The choline formed by $\mathrm{ACh}$ hydrolysis was then measured. $\mathrm{ACh}$ was quantified by measuring the height of the peaks using ACh standards submitted to the same treatment as the sample. In addition, an aliquot of $\left[{ }^{14} \mathrm{C}\right.$ ]acetylcholine was used to determine the recovery rate. The labelled compound (145,003 dpm) was added for a parallel run and extracted with benzene as described above. All radioactivity $(146,453 \mathrm{dpm})$ was found in the water extract and measured in a liquid scintillation spectrophotometer (LKB, Rack Beta, 'Primo').

\section{ACh bioassay}

The assay was performed according to the procedure previously described (Gomez et al., 1973) using a strip of guinea pig ileum suspended in Tyrode solution containing $10 \mathrm{mg}$ morphine, $5 \mu \mathrm{g}$ neostigmine, and $1.0 \mu \mathrm{g}$ promethazine (phenergan) per liter, as described by Paton (1957), but following the precautions suggested by Feldberg (1945). The term ACh, as used in the bioassay, refers to material producing an acetylcholine-like effect on the guinea pig ileum. The active material was destroyed by boiling at $\mathrm{pH} 10$ for $15 \mathrm{~min}$, and the contraction of guinea pig ileum induced by 
this material was completely abolished by atropine.

\section{Results and discussion}

Fig. 1 shows the results of light emission by the chemiluminescent assay of 20 pmol ACh standard analyzed under different experimental conditions. The presence of $0.01 \mathrm{mmol} / \mathrm{l}$ eserine free base (peak 2) or $0.01 \mathrm{mmol} / 1$ eserine hemisulphate (peak 3) in the solution of $\mathrm{ACh}$ standards reduced light emission by 22 and 30\%, respectively (compare peaks 1 with 2 and 3 ). This inhibition means a corresponding reduction in the value of $\mathrm{ACh}$, and is caused by the presence of the cholinesterase inhibitor. Washing the eserine free base-containing ACh standard with benzene gives a light emission identical (about $12 \mathrm{mV}$; peak 5) to that obtained for the control $\mathrm{ACh}$ standard without cholinesterase inhibitor (peak 1). This means that benzene washing removed the inhibitor, or eserine free base, in the chemiluminescent ACh assay. The ACh standard in the solution containing 0.01 $\mathrm{mmol} / 1$ eserine hemisulfate washed with benzene

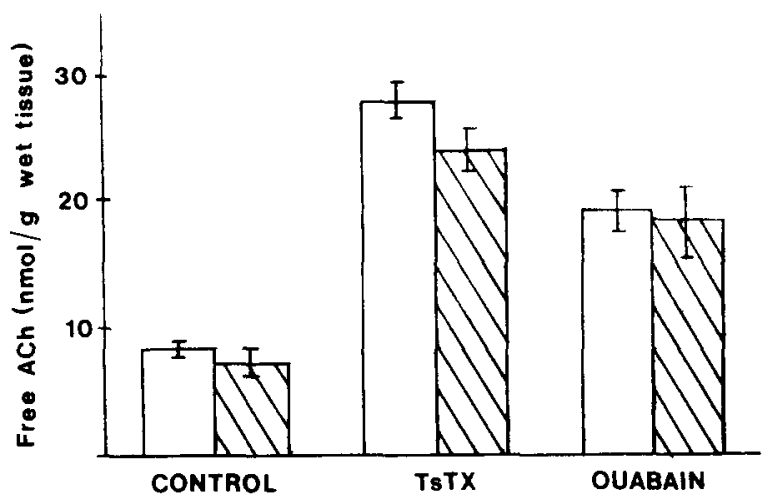

Fig. 2. Effects of $3 \mu \mathrm{mol} / 1$ tityustoxin and $10 \mu \mathrm{mol} / 1$ ouabain on the stimulated release of ACh from slices of rat cerebral cortex assayed by the modified chemiluminescent procedure (open bars) and bioassay method using guinea pig ileum (hatched bars). Incubation was carried out for $30 \mathrm{~min}$ at $\mathrm{pH}$ 7.4 in Tyrode solution containing $0.01 \mathrm{mmol} / 1$ eserine free base. The results of free $\mathrm{ACh}$ determinations are means \pm SEM of 3 experiments. See text for other details.

showed a light emission similar (peak 6) to that observed without benzene washing (peak 3). Thus washing with benzene removed eserine free base from incubation fluids, but was ineffective in removing the cholinesterase inhibitor in its polar

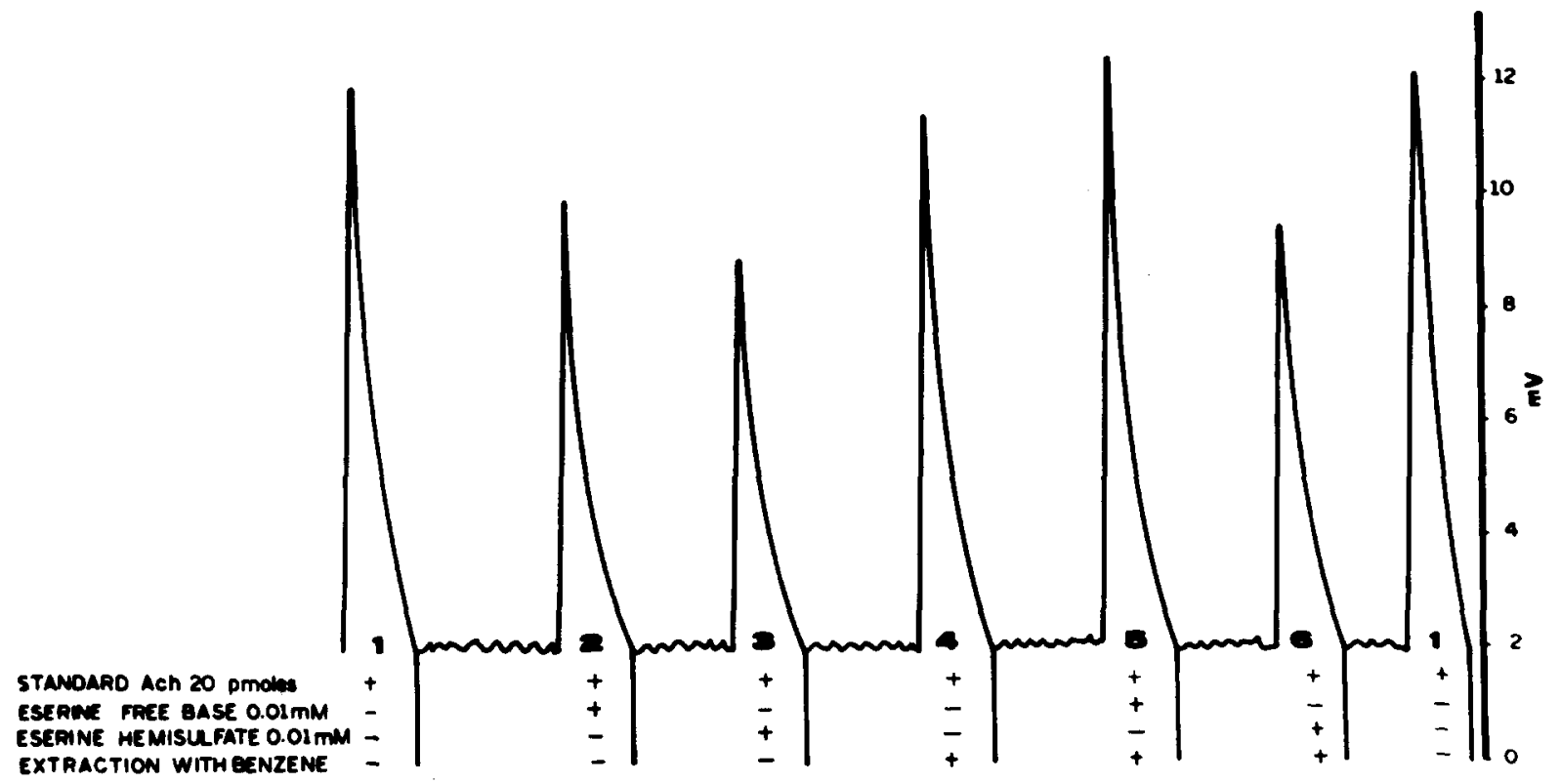

Fig. 1. Effects of eserine free base, eserine hemisulphate and extraction with benzene on light emission ( $\mathrm{mV}$ ) of $20 \mathrm{pmol}$ ACh standard assayed by the chemiluminescent method. The height of the peaks represents the light emission at the experimental conditions shown. 
form (eserine hemisulphate). Benzene-washing of the ACh standard solution without any of the cholinesterase inhibitors results in a light response similar (peak 4) to the control ACh standard (peak 1), i.e. about $12 \mathrm{mV}$. Thus, the benzene treatment does not interfere with the chemiluminescent $\mathrm{ACh}$ assay and is able to extract the eserine, which at the concentration used in the experiment, is soluble in the medium. In a parallel experiment, a sample of [methyl- $\left.{ }^{14} \mathrm{C}\right]$ acetylcholine submitted to the washing procedure with benzene showed that $100 \%$ of $\left[{ }^{14} \mathrm{C}\right] \mathrm{ACh}$ remains in the washed solution. In view of the fact that the inhibition of light emission caused by eserine free base totally disappeared after washing with benzene, no attempt was made to quantify the amount of cholinesterase inhibitor remaining in the washed extracts.

Fig. 2 shows the results of an experiment in which the method was applied to assay endogenous $\mathrm{ACh}$ released from rat brain cortical slices stimulated for $30 \mathrm{~min}$ with tityustoxin or ouabain (Gomez et al., 1973). In this experiment, ACh released into the incubating medium containing $0.01 \mathrm{mmol} / 1$ eserine free base was analyzed by the modified chemiluminescent method described here, as well as by a bioassay using guinea pig ileum. As can be seen, no statistical differences in the release of $\mathrm{ACh}$ were observed for either method. The present method is thus suitable for in vitro and in vivo determinations of $\mathrm{ACh}$, even in the presence of the cholinesterase inhibitor, eserine free base. Besides a complete recovery of $\left[{ }^{14} \mathrm{C}\right] \mathrm{ACh}$, the modified procedure showed results comparable to the biological assay. The method is, therefore, highly recommended for determining $\mathrm{ACh}$, as opposed to the procedure which uses $\mathrm{ACh}$ precipitation by periodate which yields a very low recovery of around 30\% (Haggblad et al., 1983).

\section{Acknowledgements}

Research supported by Finep, CNPq, Fapemig and CPq-UFMG. We thank V.M. Silva and E. Santos for technical assistance and D.L. Nelson for reading the manuscript. M.V.G. and T.M.-S. are Research Fellows from $\mathrm{CNPq}$.

\section{References}

Feldberg, W. (1945) Synthesis of acetylcholine by tissue central nervous system. J. Physiol., 103: 367-402.

Goldberg, A.M. and McCannan, R.C. (1973) The determination of picomole amounts of acetylcholine in mammalian brain. J. Neurochem., 20: 1-8.

Gomez, M.V., Dai, M.E.M. and Diniz, C.R. (1973) Effect of scorpion venom tityustoxin on the release of acetylcholine from incubated slices of rat brain. J. Neurochem., 20: 1051-1062.

Haggblad, J., Eriksson, H. and Heilbroun, E. (1983) Microanalysis of endogenous acetylcholine released from the hemidiaphragm of the rat. J. Neurochem., 40: 1581-1584.

Israel, M. and Lesbats, B. (1981a) Chemiluminescent determination of acetylcholine and continuous detection of its release from Torpedo electric organ synapses and synaptosomes. Neurochem. Lnc., 3: 81-90.

Israel, M. and Lesbats, B. (1981b) Continuous determination by a chemiluminescent method for detecting acetylcholine. J. Neurochem., 39: 248-250.

Israel, M. and Lesbats, B. (1982) Application to mammalian tissue of the chemiluminescent method for detecting acetylcholine. J. Neurochem., 39: 248-250.

Jenden, D.J., Roch, M. and Booth, R.B. (1973) Simultaneous measurements of endogenous and deuterium labelled tracer variants of choline and acetylcholine in subpicomole quantities by gas chromatography mass spectrometry. Anal. Biochem., 55: 438-448.

MacIntosh, F.C. and Perry, W.L.M. (1950) Biological estimates of acetylcholine. In: R.W. Gerrard (Ed.), Methods in Medical Research, Vol. 3, Year-Book, Chicago, IL, pp. 78-96.

Paton, W.D.M. (1957) The action of morphine and related substances on contraction on acetylcholine output of coaxially stimulated guinea pig ileum. Br. J. Pharmacol. Chemother., 12: 119-127.

Potter, P.E., Meek, J.L. and Neff, N.H. (1983) Acetylcholine and choline in neuronal tissue measured by HPLC with electrochemical detection. J. Neurochem., 41: 288-294. 